\title{
Nutritional profiling of the edible seaweeds Gracilaria edulis, Ulva lactuca and Sargassum sp.
}

\author{
JESMI DEBBARMA ${ }^{1}$, B. MADHUSUDANA RAO ${ }^{1}$, L. NARASIMHA MURTHY ${ }^{2}$, \\ SUSEELA MATHEW $^{3}$, G. VENKATESHWARLU ${ }^{4}$ AND C. N. RAVISHANKAR ${ }^{3}$ \\ ${ }^{1}$ Visakhapatnam Research Centre of ICAR-Central Institute of Fisheries Technology, Visakhapatnam - 530003 , \\ Andhra Pradesh \\ ${ }^{2}$ Mumbai Research Centre of ICAR-Central Institute of Fisheries Technology, Mumbai - 400 703, Maharashtra, India \\ ${ }^{3} I C A R$ - Central Institute of Fisheries Technology, Kochi - 682 029, Kerala, India \\ ${ }^{4}$ Indian Council of Agricultural Research, New Delhi -110 001, India \\ e-mail: jessmi.cife@gmail.com
}

\begin{abstract}
In the present study, nutritional composition of the edible seaweeds, Gracilaria edulis (red seaweed), Ulva lactuca (green seaweed) and Sargassum sp. (brown seaweed) were evaluated. Results showed that the seaweeds had protein content of $13.84 \pm 3.55$ to $18.21 \pm 0.00 \%$; fat $0.73 \pm 0.001$ to $0.93 \pm 0.00 \%$, carbohydrate $30.32 \pm 0.21$ to $43.19 \pm 1.75 \%$ and total dietary fibre (TDF) content of $53.625 \pm 0.18$ to $63.175 \pm 0.46 \%$ on dry weight basis. Among the three seaweeds, Sargassum sp. contained highest protein content $(18.21 \pm 0.00 \%)$ and G. edulis possessed highest TDF $(63.175 \pm 0.46 \%)$. Macronutrients viz., $\mathrm{Na}, \mathrm{P}$ and $\mathrm{Ca}$ and the micronutrients $\mathrm{Fe}, \mathrm{Se}, \mathrm{Mn}, \mathrm{Cu}$ and $\mathrm{Zn}$ were present in all three seaweeds. G. edulis had highest $\mathrm{Na}$

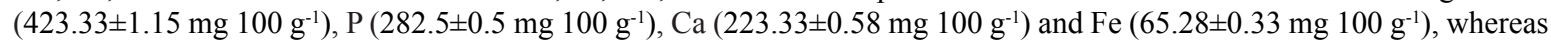
highest Se content was recorded in Sargassum sp (49.82 $\left.\pm 0.09 \mathrm{mg} 100 \mathrm{~g}^{-1}\right)$. Palmitic acid (C16:0), oleic acid (C18:1) and linoleic acid (C18:2, $\omega-6)$ were the most abundant saturated fatty acid (SFA), monounsaturated fatty acid (MUFA) and polyunsaturated fatty acid (PUFA), respectively. Fatty acid profile also revealed that small quantity of docosahexaenoic acid (DHA) (C22:6, $\omega-3)$ ranging from 0.064 to $0.494 \%$ was present in all the three seaweed species but eicosapentaenoic acid (EPA) (C20:5, $\omega-3)$ was present only in Sargassum sp. at a concentration of $0.583 \%$. G. edulis had higher vitamin D2 (2.590

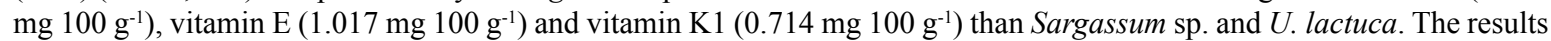
clearly indicates that these three seaweeds can be considered as a good source of dietary fibre, protein, minerals and vitamins and can be used for fortifying foods or as components of functional foods.
\end{abstract}

Keywords: Gracilaria edulis, Minerals, Nutritional profiling, Sargassum sp., Total dietary fibre, Ulva lactuca, Vitamins

\section{Introduction}

Seaweeds have been commonly utilised as a component of oriental diets, especially in Japan, China and Korea since ancient times owing to the presence of beneficial nutrients (Murata and Nakazoe, 2001; Prabhasankar et al., 2009). World wide, $65 \%$ of the commercially exploited seaweeds are being used for human nutrition (Zemke-White and Ohno, 1999). During 2005, total global seaweed production was 16.1 million $\mathrm{t}$, of which 8 and $92 \%$ were from capture and culture, respectively (FAO, 2007). In Japan, seaweeds have been used for preparation of different types of products such as jam, cheese, wine, tea, soups and noodles (Nisizawa et al., 1987) and the per capita consumption is more than $1.6 \mathrm{~kg} \mathrm{year}^{-1}$ (dry weight) (Fleurence, 1999). Additionally, seaweeds are major source of phycocolloids extraction (agar, algin and carrageenan) for several industrial applications like pharmaceutical, cosmetics and the food industry as gelling, stabilising and thickening agents (Jimenez-Escrig and Sanchez-Muniz, 2000). Moreover, direct consumption of seaweeds as human food has been increasing in recent decades in western countries and other parts of the world.

Seaweeds are considered healthy food owing to their richness in protein, vitamins, minerals and bioactive compounds, at the same time having relatively lower calorie content (Lee et al., 2008; Gomez et al., 2010). The nutrient profile of seaweeds is influenced by diverse factors such as seaweed species, habitat, maturity stage, season, temperature and the sampling conditions (Khotimchenko et al., 2005; Renaud and Luong-Van, 2006). Gupta and Abu-Ghannam (2011) observed relatively higher carbohydrate content in red and green seaweeds and higher content of soluble fiber and iodine in brown seaweeds. Seaweeds are also a good source of dietary fibre, which includes soluble as well as insoluble dietary fibres (based on solubility in water). Soluble dietary fibre helps to increase viscosity and reduce glycemic response and plasma cholesterol in humans (Venugopal, 2008; Elleuch 
et al., 2011). Insoluble dietary fibres are responsible for bulking effect caused by high water absorption capacity which is attributed in weight management, improvement in cardiovascular and gastrointestinal health and cancer prevention (Braithwaite et al., 2014). Most recently seaweeds are recognised as ingredients for functional food family, due to their extraordinary nutritional as well as nutraceutical properties (Shahidi, 2009).

Porphyra sp., Laminaria sp., Undaria sp., Sargassum sp., Ulva sp., Euchema sp. and Gracilaria sp. are the commonly used seaweeds for human consumption. Gracilaria edulis (red seaweed), Ulva lactuca (green seaweed) and Sargassum sp. (brown seaweed), are grown abundantly and harvested in large quantities in both east and west coasts of India. Their utilisation is mostly restricted to phycocolloids extraction, as fertiliser for agriculture and animal feeds in India (Kaliaperumal, 1993). Even though, several studies have been conducted on nutritional aspects of seaweed, very little work has been done on this aspect in India. Moreover, most of the studies on nutrients of seaweeds have been concentrated on fresh weeds and very little attention has been paid to dried seaweeds. Hence this study was conducted to determine the proximate composition, dietary fibre, minerals, fatty acid profile and fat soluble vitamins profile of shade dried $G$. edulis, U. lactuca and Sargassum sp. Studies on chemical composition will provide more knowledge on nutritional aspects of these seaweeds. This information might increase the possibilities of their consumption as a vegetable diet and as nutrient supplement in India, where seaweeds are not consumed traditionally.

\section{Materials and methods}

Sample collection

The seaweeds G. edulis (red seaweed), U. lactuca (green seaweed) and Sargassum sp. (brown seaweed) were collected from Mandapam, Tamil Nadu, India. Seaweed samples were handpicked and cleaned with seawater to remove foreign particles, grit particles and epiphytes. The seaweeds were cleaned thoroughly using potable water in the laboratory and dried under shade (2 - 3 days), powdered, vacuum packed and stored at room temperature.

\section{Chemical analysis}

Moisture, protein, fat, carbohydrate, ash, calcium $(\mathrm{Ca})$, potassium $(\mathrm{K})$ and sodium $(\mathrm{Na})$ were estimated as per standard methods (AOAC, 1990). Iron (Fe), zinc (Zn), copper $(\mathrm{Cu})$, manganese $(\mathrm{Mn})$, cobalt $(\mathrm{Co})$, and selenium $(\mathrm{Se})$ were analysed following AOAC (2000) with Atomic Absorption Spectrophotometer (Varian Spectra AA 220, Australia).

\section{Dietary fibre}

Total dietary fibre (TDF) was estimated by digesting the seaweed samples using $\alpha$-amylase, amyloglucosidase, and protease (AOAC, 1997).

\section{Fatty acid analysis}

Total lipid extraction and fatty acid profiling were carried out by gas chromatography ( Varian CP 3800, USA) (Folch et al., 1957; AOAC, 2000).

\section{Fat soluble vitamin analysis}

Seaweed samples were subjected to lipid extraction (Folch et al., 1957) and saponification (AOAC, 2000). About $150 \mathrm{mg}$ of seaweed lipids was refluxed with methanolic $\mathrm{KOH}$ under $\mathrm{N}_{2}$ in a water bath for half an hour and then the fat soluble vitamins were extracted with petroleum ether, identified and quantified by high performance liquid chromatography (HPLC; Shimadzu LC 10AS) equipped with C18 Reversed Phase column and ultraviolet (UV) detector as per Chatzimichalakis et al. (2004) using acetonitrile and methanol in the simple linear gradient system.

\section{Statistical analysis}

All results are presented on dry weight basis (DWB). Variation in the nutrient component of seaweeds were tested at $5 \%$ probability level using one way analysis of variance (ANOVA) followed by Duncan's multiple range test. All the analyses were carried out using SPSS software version 16.0.

\section{Results and discussion}

Proximate composition and total dietary fibre (TDF)

Proximate composition of seaweeds namely G. edulis, U. lactuca and Sargassum sp. is presented in Table 1. Protein content of seaweeds ranged from $13.84 \pm 3.55$ to $18.21 \pm 0.00 \%$ on DWB. The highest protein content was found in brown

Table 1. Nutritional composition of Gracilaria edulis, Sargassum sp. and Ulva lactuca

\begin{tabular}{|c|c|c|c|}
\hline Nutritional composition ( $\%$ dry weight basis) & Gracilaria edulis & Sargassum sp. & Ulva lactuca \\
\hline Moisture & $87.14 \pm 1.10^{b}$ & $81.84 \pm 1.41^{\mathrm{a}}$ & $84.81 \pm 0.22^{\mathrm{ab}}$ \\
\hline Protein & $14.26 \pm 0.88^{\mathrm{a}}$ & $18.21 \pm 0.00^{\mathrm{a}}$ & $13.84 \pm 3.55^{\mathrm{a}}$ \\
\hline Fat & $0.93 \pm 0.00^{\mathrm{c}}$ & $0.73 \pm 0.001^{\mathrm{a}}$ & $0.86 \pm 0.00^{\mathrm{b}}$ \\
\hline Ash & $7.63 \pm 0.11^{\mathrm{a}}$ & $12.95 \pm 0.35^{\mathrm{b}}$ & $12.41 \pm 0.32^{\mathrm{b}}$ \\
\hline Carbohydrate & $32.39 \pm 1.90^{\mathrm{a}}$ & $30.32 \pm 0.21^{\mathrm{a}}$ & $43.19 \pm 1.75^{\mathrm{b}}$ \\
\hline Total dietary fibre (TDF) & $63.175 \pm 0.46^{\mathrm{c}}$ & $58.25 \pm 0.35^{\mathrm{b}}$ & $53.625 \pm 0.18^{\mathrm{a}}$ \\
\hline
\end{tabular}

Values within a row with different superscripts are significantly different $(p<0.05)$ 
seaweed Sargassum sp. at a concentration of $18.21 \pm 0.00 \%$ followed by $G$. edulis $(14.26 \pm 0.88 \%)$ and $U$. lactuca $(13.84 \pm 3.55 \%)$. There was no significant difference ( $>0.05$ ) of protein content among the three seaweed species. However, higher protein content of seaweeds was observed in present study as compared to previous reports (Wong and Cheung, 2000; Syad et al., 2013; Sakthivel and Devi, 2015) of $0.668 \pm 0.10 \%$ in $G$. edulis, $0.061 \pm 0.01 \%$ in Gracilaria acerosa; $0.15 \pm 0.02 \%$ in $S$. wightii and $7.06 \pm 0.06 \%$ in U. lactuca.

In the present study, lipid content (Table 1) ranged from $0.73 \pm 0.001$ to $0.93 \pm 0.00 \%$; with highest level in G. edulis $(0.93 \pm 0.00 \%)$ and lowest in Sargassum sp. $(0.73 \pm 0.001 \%)$. In general, seaweeds are low in lipid content ranging from 1 to 3\% (Mabeau and Fleurence, 1993). The lipid content previously reported for G. edulis was $0.83 \pm 0.1 \%$ (Sakthivel and Devi, 2015) and in G. acerosa, a related species, was $2.8 \pm 0.01 \%$ (Syad et al., 2013), which were higher than recorded in the present study for G. edulis. Lipid content of Sargassum sp. and U. lactuca were $0.73 \pm 0.001 \%$ and $0.86 \pm 0.00 \%$, respectively. Contrary to this study, Wong and Cheung (2000) and Syad et al. (2013) reported lipid content of $2.72 \pm 0.36 \%$ in $S$. wightii and $1.64 \pm 0.10 \%$ in U. lactuca. However, significant difference $(\mathrm{p}<0.05)$ was observed in lipid content among the three seaweeds studied.

Ash content ranged from $7.63 \pm 0.11$ to $12.95 \pm 0.35 \%$, which was higher than previous reports (Pak and Araya, 1996a; b). Seaweeds have higher ash content than most of the vegetables (Rupe'rez et al., 2002). Ash content in G. edulis differed significantly $(\mathrm{p}<0.05)$ from that of $U$. lactuca and Sargassum sp., with no significant difference $(\mathrm{p}>0.05)$ in ash content between the latter two species.

$U$. lactuca showed highest carbohydrate content $(43.19 \pm 1.75 \%)$, which differed significantly $(\mathrm{p}<0.05)$ from carbohydrate content of Sargassum sp. Sakthivel and Devi (2015) reported total carbohydrate content of G. edulis to be $10.16 \pm 1.8 \%$, which is considerably lower than the total carbohydrate content of $G$. edulis recorded in this study. Wong and Cheung (2000) reported carbohydrate content of the red algae Hypnea japonica, H. charoides and U. lactuca as $4.28 \pm 1.52 \%, 7.02 \pm 4.06 \%$ and $14.6 \pm 4.94 \%$, respectively, which were all lower than the carbohydrate content of seaweeds recorded in the present study.

Highest TDF was found in G. edulis $(63.175 \pm 0.46 \%)$ followed by Sargassum sp. (58.25 $\pm 0.35 \%)$ and U. lactuca $(53.625 \pm 0.18 \%)$. Significant difference $(p<0.05)$ in dietary fibre content were observed among the three different seaweeds. The TDF content of seaweeds reported in the present study is in agreement with that of previous studies (Ortiz et al., 2006; Dawczynski et al., 2007). Sakthivel and Devi (2015) reported $8.9 \pm 0.62 \%$ dietary fibre in G. edulis, which is much lower than our observation of the same species. Dietary fibre has been consumed for its health beneficial properties such as prevention of cardiovascular disease, diabetes, prevention of constipation issues as well as colon cancer (Elleuch et al., 2011; Braithwaite et al., 2014). Hence, seaweed dietary fibre can be utilised as a potential alternative source to cereal based fibres.

The wide dissimilarity in the nutritional composition observed in the three seaweed species in our study could be attributed to diverse factors such as variations in geographical location, season, sunlight intensity, temperature and salinity (Marinho-Soriano et al., 2006).

\section{Macro and micro mineral composition}

Seaweeds are a major source of macro and micro minerals. Mineral content of G. edulis, Sargassum sp. and U. lactuca are presented in Table 2 .

Macro minerals, namely $\mathrm{Na}, \mathrm{K}$ and $\mathrm{Ca}$ are inorganic elements and required in relatively large quanities for various key physiological functions such as body fluid regulation, electrolyte balance, muscle contraction, blood clotting, $\mathrm{Fe}$ utilisation and regulation of hypertension in the human body. Results of macronutrient analysis shows that seaweeds are rich in $\mathrm{Na}, \mathrm{K}$ and $\mathrm{Ca}$ content. Among all the three seaweeds,

Table 2. Mineral composition of Gracilaria edulis, Sargassum sp. and Ulva lactuca

\begin{tabular}{llll}
\hline Minerals (mg \%) & Gracilaria edulis & Sargassum $\mathrm{sp}$. & Ulva lactuca \\
\hline Macronutrients & & & $351.67 \pm 1.53^{\mathrm{a}}$ \\
$\mathrm{Na}$ & $423.33 \pm 1.15^{\mathrm{c}}$ & $389.33 \pm 0.58^{\mathrm{b}}$ & $209.00 \pm 1.73^{\mathrm{a}}$ \\
$\mathrm{K}$ & $282.5 \pm 0.5^{\mathrm{c}}$ & $244.33 \pm 1.15^{\mathrm{b}}$ & $180.67 \pm 1.15^{\mathrm{b}}$ \\
$\mathrm{Ca}$ & $223.33 \pm 0.58^{\mathrm{c}}$ & $176 \pm 1.73^{\mathrm{a}}$ & $34.47 \pm 1.10^{\mathrm{a}}$ \\
\hline $\mathrm{Micronutrients}$ & & & $1.78 \pm 0.02^{\mathrm{a}}$ \\
$\mathrm{Fe}$ & $65.28 \pm 0.33^{\mathrm{b}}$ & $32.21 \pm 1.57^{\mathrm{a}}$ & $1.83 \pm 0.005^{\mathrm{c}}$ \\
$\mathrm{Zn}$ & $1.7 \pm 0.06^{\mathrm{a}}$ & $5.81 \pm 0.06^{\mathrm{b}}$ & $1.60 \pm 0.04^{\mathrm{a}}$ \\
$\mathrm{Cu}$ & $1.78 \pm 0.01^{\mathrm{b}}$ & $1.62 \pm 0.02^{\mathrm{a}}$ & $4.8 \pm 0.02^{\mathrm{a}}$
\end{tabular}

Results are mean \pm standard deviation. Values within a row with different superscripts are significantly different $(\mathrm{p}<0.05)$ 
G. edulis possessed highest $\mathrm{Na}(423.33 \pm 1.15 \mathrm{mg} \%), \mathrm{K}$ $(282.5 \pm 0.5 \mathrm{mg} \%), \mathrm{Ca}(223.33 \pm 0.58 \mathrm{mg} \%)$ content and least were found in U. lactuca. However, content of $\mathrm{Na}, \mathrm{K}, \mathrm{Ca}$ differed significantly $(\mathrm{p}<0.05)$ among all seaweeds studied. Sakthivel and Devi (2015) reported much lower values of $\mathrm{Na}$, $\mathrm{K}$ and $\mathrm{Ca}$ in G. edulis than the values obtained in the present study. $\mathrm{Na}(351.67 \pm 1.53 \mathrm{mg} \%), \mathrm{K}(209.00 \pm 1.73 \mathrm{mg} \%)$ and $\mathrm{Ca}(180.67 \pm 1.15 \mathrm{mg} \%)$ content in U. lactuca observed in our study were lower than that determined by Yaich et al. (2011). In the present study $\mathrm{Na}, \mathrm{K}$ and $\mathrm{Ca}$ content in Sargassum sp. was $389.33 \pm 0.58 \mathrm{mg} \%, 244.33 \pm 1.15 \mathrm{mg} \%$ and $176 \pm 1.73$ $\mathrm{mg} \%$, respectively. The differences in macronutrients content in seaweeds could be a result of variations in climate and location (Marinho - Soriano et al., 2006).

Micro minerals namely $\mathrm{Fe}, \mathrm{Cu}, \mathrm{Zn}, \mathrm{Mn}$ and Se though needed only in trace amounts, are significant in regular functioning of the human body. Among the seaweeds studied, Fe content was significantly higher $(\mathrm{p}<0.05)$ in $G$. edulis $(65.28 \pm 0.33 \mathrm{mg} \%)$ followed by $U$. lactuca $(34.47 \pm 1.10$ $\mathrm{mg} \%)$ and Sargassum sp. (32.21 $\pm 1.57 \mathrm{mg} \%)$. Fe content in our study was relatively higher than that reported by other authors (MacArtain et al., 2007; Matanjun et al., 2009). According to the $\mathrm{WHO}$, around 2 billion people of the world are affected by $\mathrm{Fe}$ deficiency leading to increased fatal pregnancy and morbidity in children (WHO, 2015). Results of the present study demonstrated that seaweeds could be used as a source of Fe to combat iron deficiency disorders.

In present study, $\mathrm{Zn}$ content of seaweeds varied from $1.7 \pm 0.06$ to $5.81 \pm 0.06 \mathrm{mg} \%$. Significantly higher $(\mathrm{p}<0.05) \mathrm{Zn}$ content was found in Sargassum $\mathrm{sp} . \mathrm{Cu}$ is necessary for Fe utilisation in body and as a cofactor for enzymes which metabolise glucose and for synthesis of hemoglobin, connective tissue and phospholipids (Celik and Oehlenschlaager, 2004). Significantly higher $(p<0.05) \mathrm{Cu}$ content was observed in U. lactuca $(1.83 \pm 0.005 \mathrm{mg} \%)$.

Selenium is an essential trace mineral of immense significance to human health and is well known as an antioxidant and catalyst for thyroid hormone production (Rayman, 2000). Se content of the three seaweeds showed wide range from $1.60 \pm 0.04$ to $49.82 \pm 0.09 \mathrm{mg} \%$ with higher $(\mathrm{p}<0.05)$ content in Sargassum sp. $(49.82 \pm 0.09 \mathrm{mg} \%)$. Lowest content was found in U. lactuca.

Manganese is vital for the formation of bones, connective tissues, sex hormones and clotting of blood. It is also involved in metabolism of fat and carbohydrate, absorption of calcium and regulation of blood sugar as well as for brain and nerve function. All three seaweeds were found rich in $\mathrm{Mn}$ and the contents ranged from $3.27 \pm 0.25$ to $4.8 \pm 0.02 \mathrm{mg} \%$ and there was no significant $(\mathrm{p}>0.05)$ difference in manganese content among the three seaweeds.
This study revealed that seaweeds are a good source of macro and micro nutrients. Essential mineral content in seaweeds are at much higher levels than many terrestrial mineral sources such as spinach (Savindra et al., 2015). Dietary reference intake recommends that approximately 25 $\mathrm{g}$ of seaweed in a day can fulfill the mineral requirements in adult human (Gebhardt and Thomas, 2002).

\section{Fatty acid composition}

Palmitic acid (C16:0) was the most dominant saturated fatty acid (SFA) in the seaweed samples analysed (Table 3). The amount of palmitic acid (C16:0) was highest in G. edulis $(65.01 \%)$ followed by U. lactuca $(61.10 \%)$ and Sargassum sp. (43.10\%). Dominance of palmitic acid has been reported by other authors for U. lactuca and Porphyra sp. (Ortiz et al., 2006; Dawczynski et al., 2007; Yaich et al., 2011). Seaweeds studied in our study also had negligible levels of myristic acid (C14:0) (1.09 to $1.66 \%)$ and stearic acid (C18:0) (1.46 to $1.73 \%)$.

Oleic acid (C18:1) was the most dominant monounsaturated fatty acid (MUFA) in the seaweeds and it ranged from 16.61 to $19.66 \%$. Higher content of C18:1 was found in Sargassum sp. than in G. edulis and $U$. lactuca (Table 3). Oleic acid was also present in similar quantities in Porphyra sp. and Laminaria sp., whereas lower concentrations were reported in Undaria pinnatifida and Hizikia fusiforme than the values observed in this study (Dawczynski et al., 2007). Small quantity of palmitoleic acid (C16:1) was present in Sargassum sp. $(2.74 \%)$. Fatty acid analysis revealed that seaweeds also have essential fatty acids viz., linoleic acid (C18:2, $\omega-6)$ and $\alpha$-linolenic acid $(\mathrm{C} 18: 3, \omega-3)$ in the range of 8.24 to $10.25 \%$ and 0.48 to $2.56 \%$, respectively. Linoleic acid level in $U$. lactuca $(1.72 \pm 0.91 \%)$ reported by Ortiz et al. (2006) was lower than our observation for the same species. Syad et al. (2013) reported presence of SFA and unsaturated fatty acids (USFA) in the red alga G. acerosa, but their values were lower than the observed values for G. edulis, Sargassum sp. and U. lactuca in the present study.

Present study revealed, the presence of small quantities of $\omega-3$ polyunsaturated fatty acid (PUFA) docosahexaenoic acid (DHA; C22:6; 0.06 to $0.50 \%$ ) in all the three seaweeds, whereas eicosapentaenoic acid (EPA; C20:5) was present only in Sargassum sp. (0.58 \%). Kumari et al. (2010) also demonstrated the presence of $\omega$-3 PUFA such as stearidonic acid (18:4), EPA and DHA in seaweeds. Health benefits of $\omega-3$ PUFA in particular EPA and DHA are well documented (Lauritzen, et al., 2001). Our study revealed that all three seaweeds are rich in both saturated and unsaturated fatty acids. 
Table 3. Fatty acid profile of Gracilaria edulis, Sargassum sp. and Ulva lactuca

\begin{tabular}{llll}
\hline \multirow{2}{*}{ Fatty acids } & \multicolumn{3}{c}{ \% of total fatty acids } \\
\cline { 2 - 4 } & Gracilaria edulis & Sargassum sp. & Ulva lactuca \\
\hline SFA & & nd & nd \\
\hline C12:0 & 0.13 & 1.61 & 1.09 \\
C14:0 & 1.66 & 0.26 & 0.35 \\
C15:0 & 0.66 & 43.10 & 61.10 \\
C16:0 & 65.01 & 0.16 & 0.17 \\
C17:0 & nd & 1.64 & 1.46 \\
C18:0 & 1.73 & 1.12 & 0.28 \\
C20:0 & nd & 0.06 & nd \\
C21:0 & nd & 0.84 & 2.25 \\
C22:0 & nd & 0.07 & nd \\
C23:0 & nd & nd & 0.07 \\
C24:0 & nd & 48.84 & 66.76 \\
Total & 69.20 & & \\
\hline MUFA & & nd & 0.15 \\
C14:1 $\omega-5$ & nd & 2.74 & 0.06 \\
C16:1 $\omega-7$ & 0.04 & 0.19 & 0.27 \\
C17:1 $\omega-7$ & 0.04 & 19.66 & 16.61 \\
C18:1 $\omega-9$ & 17.26 & 0.36 & 0.02 \\
C20:1 $\omega-9$ & nd & 22.95 & 17.12 \\
Total & 17.33 & & \\
\hline PUFA & & 9.62 & 8.24 \\
\hline C18:2 $\omega-6$ & 10.25 & 2.56 & 1.36 \\
C18:3 $\omega-3$ & 0.48 & 0.66 & nd \\
C20:2 $\omega-6$ & nd & 0.68 & nd \\
C20:3 $\omega-9$ & nd & 8.90 & nd \\
C20:4 $\omega-6$ & nd & 0.58 & nd \\
C20:5 $\omega-3$ & nd & 0.34 & 0.83 \\
C22:2 $\omega-6$ & 0.73 & 0.50 & 0.16 \\
C22:6 $\omega-3$ & 0.06 & 23.82 & 10.59 \\
Total & 11.52 & & \\
\hline
\end{tabular}

nd- not detected

Results of the present study showed that seaweeds contain high total level of SFA than MUFA and PUFA. Total level of MUFA was found to be lowest in U. lactuca and the highest concentration of PUFA was found in Sargassum sp.

\section{Fat soluble vitamins}

The content of fat soluble vitamins namely vitamin A, $\mathrm{D}, \mathrm{E}$ and $\mathrm{K}$ of G. edulis, Sargassum sp. and U. lactuca are shown in Table 4. Vitamin analyses revealed that G. edulis had highest content of vitamin D2 (2.59 mg\%) followed by vitamin $\mathrm{E}(1.02 \mathrm{mg} \%)$ and vitamin $\mathrm{K} 1(0.71 \mathrm{mg} \%)$. In Sargassum sp, vitamin E $(0.49 \mathrm{mg} \%)$ was recorded, while vitamins $\mathrm{A}, \mathrm{D} 2$ and $\mathrm{K} 1$ were below detectable levels. VitaminA was not detected in U. lactuca. However, U. lactuca possessed vitamin $\mathrm{D} 2, \mathrm{~K} 1$ and $\mathrm{E}$ at concentrations of $0.12 \mathrm{mg} \%, 0.22 \mathrm{mg} \%$ and $0.06 \mathrm{mg} \%$, respectively. Sakthivel and Devi (2015) reported that G. edulis contains vitamin A and $\mathrm{E}$, at $0.021 \mathrm{mg} \%$ and $0.013 \mathrm{mg} \%$ respectively. Ortiz et al.
Table 4. Fat soluble vitamins in Gracilaria edulis, Sargassum sp. and Ulva lactuca

\begin{tabular}{llll}
\hline $\begin{array}{l}\text { Vitamins } \\
(\mathrm{mg} \%)\end{array}$ & Gracileria edulis & Sargassum $\mathrm{sp}$. & Ulva lactuca \\
\hline Vit A & 0.001 & BDL & nd \\
Vit D2 & 2.59 & BDL & 0.12 \\
Vit K1 & 0.72 & BDL & 0.22 \\
Vit E & 1.02 & 0.49 & 0.06 \\
\hline
\end{tabular}

nd- not detected, BDL - Below detectable level.

(2006) suggested that the daily vitamin requirements of the human body could be met by consuming $100 \mathrm{~g}$ of seaweeds.

The present study indicated that the red seaweed $G$. edulis, the green seaweed U. lactuca and the brown seaweed Sargassum sp. were rich in dietary fibre, carbohydrate, protein and minerals such as $\mathrm{Na}, \mathrm{P}, \mathrm{Ca}, \mathrm{Fe}, \mathrm{Se}$, $\mathrm{Mn}, \mathrm{Cu}$ and $\mathrm{Zn}$ and also have essential fatty acids such as linoleic acid, DHA and EPA as well as fat soluble vitamins in minor quantities. G. edulis was found to have higher nutritional value compared to Sargassum sp. and U. lactuca. The results clearly indicate that the red, brown and green seaweeds are promising alternatives to land crops and can be considered as cheap sources of vegetables from sea to satiate the dietary needs of the growing population. Seaweeds can be used as fortifying ingredients to enrich the nutritional status of foods, especially in terms of dietary fibre and Fe content.

\section{Acknowledgements}

This study is part of the first author's Ph. D research at ICAR-Central Institute of Fisheries Education (ICAR-CIFE), Mumbai. The authors are thankful to the Director, ICAR-CIFE and the Head, Department of FRHPHM, ICAR-CIFE for their encouragement. Technical assistance rendered from Fish Processing Section, Visakhapatnam Research Centre of ICARCentral Institute of Fisheries Technology (ICAR-CIFT), and Biochemistry and Nutrition Division, ICAR-CIFT, Kochi is gratefully acknowledged.

\section{References}

AOAC 1990. Official methods of analysis, $15^{\text {th }}$ edn. Association of Official Analytical Chemists, Washington, DC, USA.

AOAC 1997. Officcial methods of analysis, $16^{\text {th }}$ edn. Association of Official Analytical Chemists, Washington, DC, USA.

AOAC 2000. Official methods of analysis, $17^{\text {th }}$ edn. Association of Official Analytical Chemists, Washington, DC, USA.

Braithwaite, M. C., Tyagi, C., Tomar, L. K., Kumar, P., Choonara, Y. E. and Pillay, V. 2014. Nutraceutical based therapeutics and formulation strategies augmenting their efficiency to complement modern medicine: An overview. $J$. Func. Foods, 6: 82-99.

Celik, U. and Oehlenschlaager, J. 2004. Determination of zinc and copper in fish samples collected from North-east Atlantic by DPSAV. Food Chem., 87: 343-347. 
Chatzimichalakis, P. M., Samanidou, V. F. and Papadoyannis, J. N. 2004. Development of validated liquid chromatography method for the simultaneous determination of eight fat -soluble vitamins in biological fluids after solid - phase extraction. J. Chromatogr. B., 805: 289-296.

Dawczynski, C., Schubert, R. and Jahreis, G. 2007. Amino acids, fatty acids and dietary fibre in edible seaweed products. Food Chem., 103: 891-899.

Elleuch, M., Bedigian, D., Roiseux, O., Besbes, S., Blecker, C. and Attia, H. 2011. Dietary fibre and fibre rich byproducts of food processing: Characterisation, technological functionality and commercial applications: A review. Food Chem., 124: 411-421.

FAO 2007. Year book of fishery statistics 2005. FAO, Rome, Italy

Fleurence, J. 1999. Seaweed proteins: Biochemical, nutritional aspects and potential uses. Trends Food Sci. Technol., 10(1): 25-28.

Folch, J., Lees, M. and Sloane-Stanley, G. H. 1957. A simple method for the isolation and purification of total lipids from animal tissues. J. Biol. Chem., 226: 497-509.

Gebhardt, S. E. and Thomas, R. G. 2002. Nutritive value of foods. U.S. Department of Agriculture, Agricultural Research Service, Nutrient Data Laboratory, Beltsville, Maryland, 95 pp.

Gomez-Ordonez, E., Jimenez-Escrig, A. and Ruperez, P. 2010. Dietary fibre and physicochemical properties of several edible seaweeds from the north-western Spanish coast. Food Res. Int., 43: 2289-2294.

Gupta, S. and Abu-Ghannam, N. 2011. Bioactive potential and possible health effects of edible brown seaweeds. Trends Food Sci. Technol., 22: 315-326.

Jimenez-Escrig, A. and Sanchez-Muniz, F. J. 2000. Dietary fibre from edible seaweeds: chemical structure, physicochemical properties and effects on cholesterol metabolism. Nutr. Res., 20: $585-598$

Kaliaperumal, N. 1993. Seaweed culture. In: Hand Book on Aqua Sea Urchin and Sea cucumber, MPEDA, Kochi, p. 9-22.

Khotimchenko, S. V., Vaskovsky, V. E. and Titlyanova, T. V. 2005. Fatty acids of marine algae from the Pacific coast of North California. Bot. Mar., 45(1): 17-22.

Kumari, P., Kumar, M., Gupta, V., Reddy, C. R. K. and Jha, B. 2010. Tropical marine macroalgae as potential sources of nutritionally important PUFAs. Food Chem., 120(3): 749-757.

Lauritzen, L., Hansen, H. S., Jorgensen, M. H. and Michaelsen, K. F. 2001. The essentiality of long chain $\mathrm{n}-3$ fatty acids in relation to development and function of the brain and retina. Prog. Lipid Res., 40: 1-94.

Lee, S. B., Lee, J. Y., Song, D-G., Pan, C. H., Nho, C. W. and Kim, M. C. 2008. Cancer chemopreventive effects of Korean seaweed extracts. Food Sci. Biotechnol., 17(3): 613-622.

Mabeau, S. and Fleurence, J. 1993. Seaweed in food products: Biochemical and nutritional aspects. Trends Food Sci. Tech., 4: 103-107.
MacArtain, P., Gill, C. I. R., Brooks, M., Campbell, R. and Rawland, I. R. 2007. Nutritional value of edible seaweeds, Nutr. Rev., 65(12): 535-543.

Marinho-Soriano, E., Fonseca, P. C., Carneiro, M. A. A. and Moreira, W. S. C. 2006. Seasonal variation in the chemical composition of two tropical seaweeds. Biores. Technol., 97: 2402-2406.

Matanjun, P., Mohamed, S., Mustapha, N. M. and Muhammad, K. 2009. Nutrient content of tropical edible seaweeds, Eucheuma cottonii, Caulerpa lentillifera and Sargassum polycystum, J. Appl. Phycol., 21: 75-80.

Murata, M. and Nakazoe, J. I. 2001. Production and use of marine algae in Japan. Japan Agri. Res. Q., 35: 281-290.

Nisizawa, K., Noda, H., Kikuchi, R. and Watamaba, T. 1987. The main seaweed foods in Japan. Hydrobiologia, 151/152: 5-29

Ortiz, J., Romero, N., Robert, P., Araya, J., Hernandez, J. L. and Bozzo, C. 2006. Dietary fiber, amino acid, fatty acid and tocopherol contents of the edible seaweeds Ulva lactuca and Durvillaea antarctica. Food Chem., 99: 98-104.

Pak, N. and Araya, H. 1996a. Macroalgas comestibles de Chile como fuente de fibra diete'tica: efecto en la digestibilidad aparente de prote1' nas fibra y energi' a y peso de deposiciones en ratas. Archivos Latinoamericanos de Nutricion., 46: 42-46.

Pak, N. and Araya, H. 1996b. Valor nutritivo y aportes de fibra diete'tica (soluble e insoluble) de microalgas comestibles de Chile, crudas y cocidas. Alimentos, 21: 63-69.

Prabhasankar, P., Ganesan, P. and Bhaskar, N. 2009. Influence of Indian brown seaweed (Sargassum marginatum) as an ingredient on quality, biofunctional, and microstructure characteristics of pasta. Food Sci. Technol. Int., 15: 471-479.

Rayman, M. P. 2000. The importance of selenium to human health. Lancet, 356: 233-241.

Renaud, S. M. and Luong-Van, J. T. 2006. Seasonal variation in the chemical composition of tropical Australian marine macroalgae. J. Appl. Phycol., 18: 381-387.

Rocha, S. R. D. L., Muniz, F. J. S., Gomez-juaristi, M. and Marin, M. T. L. 2009. Trace element determination in edible seaweeds by an optimised and validated ICP-MS method. J. Food Compos. Anal., 22: 330-336.

Ruperez, P., Ahrazem, O. and Leal, J. A. 2002. Potential antioxidant capacity of sulfated polysaccharides from the edibic marine brown seeweed Fucus vesiculosus. J. Agric. Food Chem., 50: $840-845$.

Sakthivel, R. and Devi, K. P. 2015. Evaluation of physicochemical properties, proximate and nutritional composition of Gracilaria edulis collected from Palk Bay. Food Chem., 174: 68-74.

Savindra, K., Dinabandhu, S. and Ira, L. 2015. Assessment of nutritional value in a brown seaweed Sargassum wightii and their seasonal variations. Algal. Res., 9: 117-125. 
Shahidi, F. 2009. Nutraceuticals and functional foods: whole versus processed foods. Trends Food Sci. Tech., 20: 376-387.

Simopoulos, A. P. 2008. The importance of the omega-6/omega-3 fatty acid ratio in cardiovascular disease and other chronic diseases. Exp. Biol. Med., 233(6): 674-688.

Syad, A. N., Shunmugiah, K. P. and Kasi, P. D. 2013. Seaweeds as nutritional supplements: Analysis of nutritional profile, physicochemical properties and proximate composition of G. acerosa and S. wightii. Biomed. Prev. Nutr., 3: 139-144.

Venugopal, V. 2008. Marine products for healthcare: Functional and bioactive nutraceutical compounds from the ocean. CRC group, Taylor \& Francis, 525 pp.
WHO 2015. Micronutrient deficiencies: iron deficiency anemia http://www.who.int/nutrition/topics/ida/en/. (Accessed 28 November 2015)

Wong, K. H. and Cheung, P. C. K. 2000. Nutritional evaluation of some subtropical red and green seaweed: Part I - Proximate composition, amino acid profiles and some physico-chemical properties. Food Chem., 71: 475-482.

Yaich, H., Garna, H., Besbes, S., Paquot, M., Blecker, C. and Attia, H. 2011. Chemical composition and functional properties of Ulva lactuca seaweed collected in Tunisia. Food Chem., 128(4): 895-901.

Zemke-White, L. W. and Ohno, M. 1999. World seaweed utilisation: end-of-century summary. J. Appl. Phycol., 11: 369-376.

Date of receipt $\quad: 19.07 .2016$

Date of acceptance : 15.09 .2016 